Ekspansi: Jurnal Ekonomi, Keuangan, Perbankan dan Akuntansi

ISSN (Online): 2580-7668 ISSN (Print): 2085-5230

Vol. 11, No. 2 (November 2019), Hal. 251 - 268

\title{
PEMERINGKATAN OBLIGASI INDUSTRI PERBANKAN DI BURSA EFEK INDONESIA BERDASARKAN RISK PROFILEDENGAN JAMINAN OBLIGASI SEBAGAI VARIABEL MODERASI
}

\author{
Erin Wijayanti ${ }^{1}$, Indah Yuliana ${ }^{2}$ \\ ${ }^{1,2}$ Fakultas Ekonomi, Universitas Islam Negeri Maulana Malik Ibrahim, Malang, Indonesia \\ Email Korespondensi: erinwijayanti00@gmail.com
}

\begin{abstract}
The purpose of this study is to determine the effect of Risk Profile in determining the ranking of banking industry bonds on the Indonesia Stock Exchange (IDX) and having a bond rating at PT. PEFINDO. The Risk Profile studied is credit risk which was proxied by the Non Performing Loan (NPL) ratio and liquidity risk which was proxied by the Loan to Deposit Ratio (LDR) ratio. Samples were selected by purposive sampling method. The population in this study are banks listed on the Indonesia Stock Exchange in 2015-2018. The population was 44 banks and 16 banks were selected as samples in this study. The analysis technique in this study uses descriptive statistics and Partial Least Square (PLS) for testing structural and structural models. The results of this study are: 1) Non Performing Loans (NPL) and Loan to Deposit Ratio (LDR) directly have a significant effect, 2) Secure directly do not have a significant effect, 3) Secure strengthen risk relationships credit with a bond rating, 4) Secure weakens the relationship between liquidity risk and the bond rating. The variables used in the study can explain the bond rating of $48.8 \%$ while the remaining $51.2 \%$ is influenced by other variablesl.
\end{abstract}

Keywords: Bond Rating, Credit Risk, Liquidity Risk, Non-Performing Loans (NPL), Loan to Deposit Ratio (LDR) and Secure.

Abstrak: Tujuan dari penelitian ini adalah untuk mengetahui pengaruh Risk Profile dalam menentukan peringkat obligasi industri perbankan di Bursa Efek Indonesia (BEI) dan memiliki peringkat obligasi di PT. Pefindo. Risk Profile yang diteliti yakni risiko kredit yang diproksikan dengan rasio Non Performing Loan (NPL) dan risiko likuiditas yang diproksikan dengan rasio Loan to Deposit Ratio (LDR). Sampel dipilih dengan metode purposive sampling. Populasi dalam penelitian ini adalah bank yang terdaftar di Bursa Efek Indonesia pada tahun 2015-2018. Jumlah populasi adalah 44 bank dan dipilih 16 bank sebagai sampel dalam penelitian ini. Teknik analisis dalam penelitian ini menggunakan statistik deskriptif dan Partial Least Square (PLS) untuk pengujian model pengukuran dan struktural. Hasil penelitian ini adalah: 1) Non Performing Loan (NPL) dan Loan to Deposit Ratio (LDR) secara langsung berpengaruh signifikan, 2) jaminan secara langsung tidak berpengaruh signifikan, 3) jaminan memperkuat hubungan risiko kredit dengan peringkat obligasi, 4) jaminan memperlemah hubungan risiko likuiditas dengan peringkat obligasi. Variabel pada penelitian ini menjelaskan peringkat obligasi sebesar $48.8 \%$ sedangkan sisanya sebesar $51.2 \%$ dipengaruhi oleh variabel lain yang tidak terdapat dalam model penelitian.

Kata Kunci: Peringkat Obligasi, Risiko Kredit, Risiko Likuiditas, Non Performing Loan (NPL), Loan to Deposit Ratio (LDR) dan Jaminan.

DOI: $10.35313 /$ ekspansi.v11i2.1607

Riwayat Artikel:

Diterima: 05 - 11 - 2019

Direvisi: 25 - 11 - 2019

Disetujui: 28-11 - 2019 


\section{PENDAHULUAN}

Pasar modal (capital market) merupakan pasar bertemunya investor dengan emiten (perusahaan yang menerbitkan Efek) untuk memperoleh pendanaan bagi perusahaan. Sumber pendanaan dapat berasal dari internal maupun eksternal perusahaan. Untuk pendanaan jangka pendek biasanya menggunakan hutang lancar (Current Liabilities), sedangkan pendanaan jangka panjang salah satunya adalah surat hutang (obligasi). Obligasi biasanya disebut dengan surat berharga pendapatan tetap (fixed-income securities) yang dikeluarkan oleh penerbit kepada investor, dan penerbit akan memberikan suatu return kepada investor berupa kupon yang dibayarkan secara rutin dan nilai pokok ketika obligasi tersebut mengalami jatuh tempo (Manurung, et al, 2008). Namun obligasi juga memiliki risiko salah satunya risiko likuiditas yaitu risiko yang timbul dari kemungkinan tidak likuidnya suatu obligasi di pasar sehingga susah untuk diperjualbelikan. Risiko lainnya adalah risiko default,. risiko yang dimaksud adalah ketidakmampuan emiten dalam memenuhi kewajiban keuangan (Keown et al, 2011). Salah satu sinyal yang mampu mengetahui risiko default obligasi adalah peringkat obligasi. Peringkat Obligasi diperlukan untuk menjadi pengawasan aktivitas manajemen guna melindungi investor agar terhindar dari risiko obligasi (Foster, 1986). Oleh karena itu investor dapat menilai tingkat kredibilitas suatu perusahaan dan mampu menyesuaikan strategi investasi mereka sesuai dengan perubahan peringkat yang diberikan oleh agen pemeringkat (Rating Agency) yaitu PT Pemeringkat Efek Indonesia (PEFINDO) dalam melakukan penilaian lembaga keuangan dan mengevaluasi obligasi dengan dibentuk suatu rating untuk mencerminkan perubahan signfikan dari kinerja keuangan dan bisnis perusahaan yang melibatkan kajian luas atas risiko profil industri, risiko bisnis dan risiko keuangan sehingga dapat mempengaruhi profil kredit perusahaan secara menyeluruh.

Industri perbankan menjadi sub sektor penting dalam perekonomian sebagai lembaga intermediasi yang berfungsi menyalurkan dana masyakarat ke dalam investasi aset produktif yang akan mendorong produktivitas sektor riil dan akumulasi kapital suatu negara (Bencivenga dan Smith, 1991; Hung and Cothern, 2002). Perbankan nasional yang terus terpengaruhi oleh keadaan perekonomian global dan domestik harus tetap menjaga eksistensinya dalam menjadi lembaga kepercayaan bagi masyarakat dalam menyimpan dananya maupun untuk berinvestasi. Hal ini disebabkan karena sumber pendanaan terbesar perbankan berasal dari masyarakat. Kepercayaan dari masyarakat kepada bank dapat dilihat dari tingkat kesehatan bank tersebut. Penilaian Tingkat Kesehatan Bank tertuang dalam Peraturan Otoritas Jasa Keuangan Nomor 4 /POJK.03/2016 Pasal 2 ayat 3 Bank wajib melakukan penilaian Tingkat Kesehatan baik secara individu maupun secara konsolidasi. Begitu juga Bank Indonesia telah menetapkan sistem penilaian tingkat kesehatan bank berbasis risiko yaitu dalam PBI No. 13/1/PBI/2011 tentang penilaian tingkat kesehatan bank umum dengan menggunakan pendekatan risiko (Risk-based Bank Rating/RBBR) yang mencakup penilaian terhadap empat faktor yaitu Risk Profile (Profil Risiko), Good Corporate Governance (GCG), Earnings (Rentabilitas), dan Capital (Permodalan) yang selanjutnya disebut dengan metode RGEC. Tingkat kesehatan bank merupakan aspek yang sangat 
penting bagi semua pihak (stakeholders), sehingga perkembangan industri perbankan saat ini telah memberikan andil dalam perubahan pendekatan penilaian secara internasional yang mengarah pada pendekatan pengawasan berdasarkan risiko (Hamolin \& Nuzula, 2018). Hal ini bertujuan agar bank mampu mendeteksi faktor internal dan eksternal yang dapat meningkatkan risiko dan diperoleh langkah-langkah pencegahan dan perbaikan secara efektif dan efisien (Fauziyah, 2017:17). Peningkatan eksposur risiko dan penerapan pendekatan pengawasan berdasarkan risiko tersebut akan mempengaruhi profil risiko perbankan.

Risk Profile (Profil Risiko) menurut Pramana \& Yunita (2015) merupakan penilaian terhadap risiko inheren dan kemampuan manajemen bank dalam mengelola kredit bermasalah dalam bank. Berdasarkan PBI No.13/1/PBI/2011 Risiko yang terkandung dalam profil risiko meliputi risiko kredit, risiko pasar, risiko operasional, risiko likuiditas, risiko hukum, risiko stratejik, risiko kepatuhan dan risiko reputasi, namun pada penelitian ini hanya mengambil 2 risiko yaitu risiko kredit dan risiko likuiditas. Kedua risiko ini mempunyai dampak yang positif dan negatif pada bank sesuai dengan kondisi usaha bank pada periode tertentu. Risiko kredit bertujuan untuk mengukur kemampuan penerbit obligasi dalam melakukan pelunasan pokok serta pembayaran bunga dengan tepat waktu, sedangkan risiko likuiditas untuk menggambarkan risiko yang akan terjadi jika pemilik obligasi membutuhkan dana dalam waktu cepat akan tetapi surat obligasi tidak dapat dijual pada harga yang wajar (Bursa Efek Indonesia, 2010). Pengukuran Risk Profile pada penelitian ini diproksikan dengan rasio Non Performing Loan (NPL) untuk mengukur risiko kredit dan rasio Loan to Deposit Ratio (LDR) untuk risiko likuiditas.

Laporan OJK menyebutkan profil risiko perbankan tahun 2018 masih terjaga dengan risiko kredit yang manageable disertai risiko kredit macet atau Non Performing Loan (NPL), likuiditas yang cukup memadai, serta risiko pasar yang terjaga. Eksposur risiko terhadap aset perbankan tahun 2018 sedikit meningkat dari tahun sebelumnya. Hal ini tercermin dari pertumbuhan Aset Tertimbang Menurut Risiko (ATMR) sebesar 9,88\% (yoy), naik dari 9,59\% (yoy) pada Desember 2017. Kenaikan tersebut didorong oleh meningkatnya ATMR kredit yaitu dari tahun sebelumnya 8,67\% (yoy) menjadi $10,06 \%$ (yoy). Peningkatan ini juga dipengaruhi oleh risiko kredit dengan rasio NPL yang menurun. Pada Desember 2018, rasio NPL gross tercatat sebesar 2,37\% atau turun dari tahun sebelumnya sebesar 2,59\%, diikuti turunnya NPL net menjadi 1,04\% dari $1,17 \%$ pada periode yang sama tahun sebelumnya. Begitu juga risiko likuiditas dengan rasio Loan to Deposit Ratio (LDR) perbankan naik menjadi 94,04\% pada periode laporan dibandingkan 89,87\% pada akhir tahun 2017.

Pramana \& Yunita (2015) menunjukan rasio NPL menjadi indikator dalam menggambarkan kualitas manajemen bank untuk mengelola kredit bermasalah pada bank. Semakin tinggi rasio ini, semakin buruk kualitas kredit pada bank yang menyebabkan jumlah kredit bermasalah dan kemungkinan suatu bank dalam kondisi bermasalah semakin besar. Jika kemungkinan suatu bank dalam kondisi bermasalah, maka peringkat obligasi perusahaan akan turun (Almilia, 2005; Susanto, Sutejo, dan Marciano, 2012; Arpadika, 2012, serta Pramana \& Yunita, 2015). Sedangkan rasio 
LDR menurut Dendawijaya (2003) LDR digunakan untuk mengukur seluruh jumlah kredit yang diberikan bank dengan dana yang diterima oleh bank. LDR yang tinggi mencerminkan sinyal yang baik bagi investor karena dengan tingkat likuiditas yang bagus secara tidak langsung akan mengurangi risiko gagal bayar (default) atau pelunasan kewajiban jangka panjangnya (pelunasan obligasi) sehingga berdampak pada peringkat obligasi (Nugraheni, 2010; Deasy, 2012; Malik, 2017; serta Pramana \& Yunita, 2015). Keberadaan risiko yang terkandung dalam sebuah obligasi bisa diminimalisir dengan adanya jaminan pada obligasi tersebut. Andry (2005) menyebutkan bahwa rating obligasi akan tinggi jika perusahaan menjaminkan aset yang tinggi untuk obligasi. Hal ini menjadi sinyal untuk investor bahwa obligasi pada perusahaannya aman (Magreta dan Nurmayanti, 2009; Rika, 2011; Yuliana et al, 201; dan Ayyu, 2013). Sedangkan penelitian yang dilakukan Luciana (2007), Werastuti (2015), serta Sakinah (2017) menyatakan bahwa jaminan tidak memiliki pengaruh pada peringkat obligasi, adapun Febriani et al (2011) mengemukakan bahwa jaminan tidak dapat dijadikan faktor untuk memprediksi peringkat obligasi. Hasil yang beragam dari penelitian terdahulu tentang pengaruh jaminan terhadap peringkat obligasi menjadi celah dalam penelitian ini, sehingga tujuan penelitian ini untuk mengetahui dengan adanya variabel jaminan ini memperkuat atau memperlemah pengaruh Profil risiko terhadap peningkatan peringkat obligasi dalam industri perbankan. Moderasi jaminan masih jarang dilakukan oleh penelitian lain.

\section{TINJAUAN PUSTAKA}

\subsection{Pengaruh Risk Profile terhadap Peringkat Obligasi}

Signalling Theory adalah teori yang menjelaskan tentang tanda adanya asimetri informasi antara perusahaan dan pihak luar yang digambarkan dengan laporan keuangan oleh manajemen sehingga risiko dalam obligasi mampu di prediksi melalui peringkat obligasi (Lina, 2010). Informasi-informasi tersebut menjadi sinyal kondisi keuangan perusahaan tertentu tentang kemungkinan yang terjadi terkait utang yang dimiliki (Raharja \& Sari, 2008). Oleh karenanya peringkat obligasi dapat memberikan sinyal seberapa aman suatu obligasi bagi investor melalui kualitas kredit perusahaan. Semakin baik kualitas kredit maka semakin tinggi peringkat yang diperoleh (Setyapurnama \& Norpratiwi, 2008).

Risk Profile (Profil Risiko) menurut Pramana \& Yunita (2015) merupakan penilaian terhadap risiko inheren dan kemampuan manajemen bank dalam mengelola kredit bermasalah dalam bank. Berdasarkan PBI No.13/1/PBI/2011 Risiko yang terkandung dalam profil risiko meliputi risiko kredit, risiko pasar, risiko operasional, risiko likuiditas, risiko hukum, risiko stratejik, risiko kepatuhan dan risiko reputasi; namun pada penelitian ini hanya mengambil 2 risiko yaitu risiko kredit dan risiko likuiditas. kedua risiko ini mempunyai dampak yang positif dan negatif pada bank sesuai dengan kondisi usaha bank pada periode tertentu.

Risiko kredit merupakan risiko yang berkaitan dengan kemungkinanan kegagalan debitur atau pihak lain untuk melunasi kewajiban bank, baik pokok maupun bunganya pada waktu yang telah ditentukan (Kasidi, 2014). Penilaian terhadap risiko kredit 
dalam penelitian ini dilakukan dengan menggunakan rasio Non Performing Loan (NPL) atau rasio tingkat kredit bermasalah. Menurut Komang Darmawan (2004), NPL merupakan rasio yang digunakan bank dalam menyanggah risiko kegagalan pengembalian kredit oleh debitur. Lebih lanjut Pramana \& Yunita (2015) menunjukan kemampuan rasio NPL dalam menggambarkan kualitas manajemen bank untuk mengelola kredit bermasalah pada bank. Semakin tinggi rasio ini, semakin buruk kualitas kredit pada bank yang menyebabkan jumlah kredit bermasalah dan kemungkinan suatu bank dalam kondisi bermasalah semakin besar. Jika kemungkinan suatu bank dalam kondisi bermasalah, maka peringkat obligasi perusahaan akan turun (Almilia, 2005). Hal ini menunjukan terdapat pengaruh antara rasio NPL suatu perusahaan dan peringkat obligasi. Hasil penelitian Susanto, Sutejo, dan Marciano, 2012; Arpadika, 2012, Pramana \& Yunita, 2015; Lestari \& Indriani, 2016; Prasetyo 2016; serta Malik, 2017 menunjukkan bahwa Non Performing Loan (NPL) berpengaruh negatif dan signifikan terhadap peringkat obligasi. Bentuk pengaruh yang ditimbulkan negatif yang berarti jika rasio NPL semakin tinggi maka semakin buruk kualitas kredit bank sehingga menyebabkan rendahnya peringkat obligasi, begitu pula sebaliknya jika semakin kecil rasio NPL akan berpengaruh pada tingginya peringkat obligasi.

$\mathrm{H}_{1}$ : Risiko Kredit yang diukur dengan Non Performing Loan (NPL) berpengaruh negatif terhadap peringkat obligasi

\subsection{Pengaruh Risiko Likuiditas terhadap Peringkat Obligasi}

Risiko likuiditas merupakan risiko ketidakmampuan bank dalam memenuhi kewajiban yang telah jatuh tempo (Veithzal Rivai, 2013). Analisis risiko likuiditas bertujuan untuk mengukur seberapa mampu suatu bank dalam membayar utangutangnya dan membayar kembali kepada deposannya serta dapat memenuhi permintaan kredit yang diajukan tanpa terjadi penangguhan (Merkusiwati, 2007). sehingga risiko likuiditas tidak hanya berpengaruh pada kinerja bank tapi juga berpengaruh pada reputasi bank (Jenkinson, 2008). Risiko pada penelitian ini diukur menggunakan rasio Loan to Deposit Ratio (LDR).

Menurut Dendawijaya (2003) LDR merupakan rasio antara seluruh jumlah kredit yang diberikan bank dengan dana yang diterima oleh bank. Rasio ini menunjukkan seberapa mampu suatu bank dalam memenuhi kebutuhan masyarakat berupa kredit (Taswan 2010). Apabila kredit yang disalurkan bermasalah atau mengalami kegagalan, maka bank akan mengalami kesulitan likuiditas dalam pengembalian dana yang dititipkan oleh masyarakat. Sehingga jika rasio ini semakin tinggi maka semakin tinggi efektivitas bank dalam menyalurkan kredit yang nantinya akan mencerminkan manajemen bank dan memberikan sinyal yang baik terhadap pasar. LDR yang tinggi mencerminkan sinyal yang baik bagi investor karena dengan tingkat likuiditas yang bagus secara tidak langsung akan mengurangi risiko gagal bayar (default) atau pelunasan kewajiban jangka panjangnya (pelunasan obligasi) yang diharapkan. Peringkat obligasi dapat menjadi sinyal kondisi keuangan perusahaan dan menggambarkan kemungkinan yang akan terjadi terkait utang yang dimiliki (Raharja \& Sari, 2008). Dalam penelitian terdahulu likuiditas termasuk faktor yang memprediksi prediksi obligasi (Magreta dan Nurmayanti, 2009; Lina, 2010 dan Febriani et al, 2011). 
Besarnya rasio LDR akan berpengaruh terhadap tingginya peringkat obligasi, begitu pula semakin kecilnya rasio LDR akan berpengaruh pada rendahnya peringkat obligasi (Hariyati, 2016; Susanto, Sutejo, dan Marciano, 2012 serta Fatimah, 2015) menunjukkan bahwa rasio LDR berpengaruh positif terhadap peringkat obligasi. Berbeda dengan penelitian tersebut, Almilia, 2005; Nugraheni, 2010; Deasy, 2012; Malik, 2017; serta Pramana \& Yunita, 2015; menunjukkan hubungan negatif antara LDR dengan peringkat obligasi karena semakin tinggi rasio LDR akan menyebabkan rendahnya kemampuan likuiditas bank sehingga kemungkinan suatu bank dalam kondisi bermasalah akan semakin besar dan berdampak pada penurunan rating obligasi.

$\mathrm{H}_{2}$ : Risiko likuiditas yang diukur dengan Loan to Deposit Ratio (LDR) berpengaruh positif terhadap peringkat obligasi

\subsection{Moderasi Jaminan Obligasi terhadap Risk Profile dan Peringkat Obligasi}

Tingkat resiko yang terkandung dalam sebuah obligasi dipengaruhi oleh adanya jaminan yang menyertai obligasi tersebut. Karena dengan adanya jaminan berarti perusahaan dapat meminimalisir resiko awal kepada investor. Joseph (2007) mengungkapkan bahwa jaminan merupakan salah satu aspek penting pada obligasi karena dengan adanya jaminan pada obligasi akan meyakinkan invetor bahwa perusahaan dapat menekan resiko default (gagal bayar) obligasi yang akan diterima. Oleh karena itu investor lebih menyukai obligasi yang dijamin daripada obligasi tanpa jaminan (Bristier et al, 1994). Andry (2005) menyebutkan bahwa rating obligasi akan tinggi jika perusahaan menjaminkan aset yang tinggi untuk obligasi. Hal ini menjadi sinyal untuk investor bahwa obligasi pada perusahaannya aman.

Dari penelitian yang dilakukan oleh Magreta dan Nurmayanti (2009), Rika (2011), Yuliana et al. (2011) dan Ayyu (2013), Sari dan Badjra (2016), Hasan dan Dana (2018), menyatakan bahwa, perusahaan yang menerbitkan obligasi dengan jaminan akan berpengaruh positif dan signifikan dalam memprediksi peringkat obligasi. Perusahaan yang membuat obligasi berisi jaminan dipercaya dapat memberikan peringkat yang lebih baik sehingga para investor akan merasakan aman untuk investasi karena rendahnya probabilitas gagalnya pembayaran kewajiban sebuah perusahaan. Penelitian Yuliana et al (2011) dan Rahmawati (2005) et al menyatakan bahwa jaminan memberikan pengaruh positif dan signifikan terhadap rating obligasi. Perusahaan yang membuat obligasi disertai dengan jaminan dipercaya dapat memberikan rating yang lebih baik. Sedangkan penelitian yang dilakukan Luciana (2007), Werastuti (2015), dan Sakinah (2017) dan Anto dan Wardjono (2019) menyatakan bahwa jaminan tidak memiliki pengaruh pada peringkat obligasi, adapun Febriani et al (2011) mengemukakan bahwa jaminan tidak dapat dijadikan faktor untuk memprediksi peringkat obligasi karena kenaikan jaminan dikatakan tidak berpengaruh terhadap profitabilitas kenaikan tingkat obligasi perusahaan.

$\mathrm{H}_{3}$ : Jaminan obligasi berpengaruh positif terhadap peringkat obligasi

\subsection{Moderasi Jaminan Obligasi}

Fahmi (2006) rasio keuangan menjadi sangat penting dalam analisis suatu kondisi keuangan perusahaan. Veithzal Rivai (2013) rasio likuiditas mengukur adanya risiko 
jika terjadi ketidakmampuan perusahaan dalam memenuhi kewajiban yang telah jatuh tempo. Risiko likuiditas menggambarkan risiko yang akan terjadi jika pemilik obligasi membutuhkan dana dalam waktu cepat akan tetapi surat obligasi tidak dapat dijual pada harga yang wajar (Bursa Efek Indonesia, 2010). Magreta dan Nurmayanti (2009) dan Lina (2010) dalam penelitiannya mengungkapkan rasio likuiditas yang diukur dengan Loan to Deposit Ratio (LDR) memiliki pengaruh yang positif yang signifikan terhadap peringkat obligasi perusahaan.

Risiko kredit merupakan risiko yang berkaitan dengan kemungkinanan kegagalan debitur atau pihak lain untuk melunasi kewajiban bank, baik pokok maupun bunganya pada waktu yang telah ditentukan (Kasidi, 2014). Penilaian terhadap risiko kredit dalam penelitian ini dilakukan dengan menggunakan rasio Non Performing Loan (NPL) atau rasio tingkat kredit bermasalah. Susanto, Sutejo, dan Marciano (2012); Arpadika (2012) dan Pramana \& Yunita, 2015 dalam penelitiannya mengatakan rasio kredit yang diukur dengan Non Performing Loan (NPL) memiliki pengaruh yang negatif dan signifikan terhadap peringkat obligasi perusahaan. Bentuk pengaruh yang ditimbulkan negatif yang berarti jika rasio NPL semakin tinggi maka semakin buruk kualitas kredit bank sehingga menyebabkan rendahnya peringkat obligasi, begitu pula sebaliknya jika semakin kecil rasio NPL akan berpengaruh pada tingginya peringkat obligasi.

Sehingga dengan mengetahui tingkat risiko kredit dan rasio likuiditas ini akan mencerminkan sinyal yang baik bagi investor karena dengan tingkat likuiditas yang bagus serta tingkat risiko yang rendah secara tidak langsung akan mengurangi risiko gagal bayar (default) atau pelunasan kewajiban jangka panjangnya (pelunasan obligasi) yang diharapkan. Selain itu obligasi dengan disetai jaminan juga menjadi sinyal baik karena tingkat resiko yang terkandung dalam suatu obligasi akan dapat diminimalisir (Joseph, 2007). Jaminan berpengaruh positif terhadap peringkat suatu obligasi (Magreta dan Nurmayanti, 2009); Rika (2011) dan Yuliana et al. (2011). Perusahaan yang membuat obligasi berisi jaminan dipercaya dapat memberikan peringkat yang lebih baik sehingga para investor akan merasakan aman untuk investasi karena rendahnya probabilitas gagalnya pembayaran kewajiban sebuah perusahaan.

$\mathrm{H}_{4}$ : Jaminan obligasi memperkuat pengaruh risiko kredit terhadap peringkat obligasi

$\mathrm{H}_{5}$ : Jaminan obligasi memperkuat pengaruh risiko likuiditas terhadap peringkat obligasi

\section{METODE PENELITIAN}

Populasi dalam penelitian ini adalah 44 perusahaan perbankan yang terdaftar di Bursa Efek Indonesia tahun 2015-2018. Teknik pengambilan sampel yang digunakan adalah purposive sampling method. Berikut adalah daftar 16 perusahaan perbankan sampel penelitian yang memenuhi syarat; Bank Capital Indonesia Tbk (BACA), Bank Bukopin Tbk (BBKP), Bank Negara Indonesia Tbk (BBNI), Bank Rakyat Indonesia Tbk (BBRI), Bank Tabungan Negara Tbk (BBTN), Bank Danamon Indonesia Tbk (BDMN), Bank Pembangunan Daerah Jawa Barat dan Banten Tbk (BJBR), Bank Mandiri Tbk (BMRI), Bank CIMB Niaga Tbk (BNGA), Bank Maybank Indonesia Tbk (BNII), Bank Permata Tbk (BNLI), Bank Victoria International Tbk (BVIC), Bank 
Mayapada Internasional Tbk (MAYA), Bank OCBC NISP Tbk (NISP), Bank Pan Indonesia Tbk (PNBN) dan Bank Woori Saudara Indonesia 1906 Tbk (SDRA). Jenis data yang digunakan adalah data sekunder yang diperoleh dari publikasi laporan keuangan perusahaan perbankan yang menerbitkan obligasi tahun 2015-2018 yang diakses pada website resmi BEI yaitu www.idx.co.id serta data peringkat obligasi perusahaan tahun 2015-2018 yang diperoleh dari website www.PEFINDO.com. Analisis data menggunakan statistik deskriptif dan Partial Least Square (PLS) untuk pengujian model pengukuran dan struktural. Kerangka konseptual dalam penelitian ini disajikan dalam gambar 1 dibawah ini.



Gambar 1. Kerangka Penelitian

Variabel terikat adalah peringkat obligasi, variabel ini dilihat berdasarkan peringkat yang dikeluarkan oleh PT PEFINDO yang membagi 2 kategori yaitu investmen grade (AAA, AA, A, BBB) dan non investment grade (BB, B, CCC, D) (Tandelilin, 2010). Variabel ini menggunakan interpretasi dari penelitian (Arif, 2012) yang menggunakan skoring peringkat obligasi dengan maksud bobot yang tinggi untuk peringkat yang lebih tinggi berdasarkan peringkat yang dikeluarkan oleh PEFINDO dalam tabel 1 dibawah ini.

Tabel 1. Skala Peringkat Obligasi

\begin{tabular}{|l|l|l|l|}
\hline Peringkat & Skoring & Peringkat & Skoring \\
\hline IdAAA & 20 & IdBB $^{+}$ & 10 \\
\hline IdAA+ & 19 & IdBB & 9 \\
\hline IdAA & 18 & IdBB- & 8 \\
\hline IdAA- & 17 & IdB + & 7 \\
\hline IdA+ & 16 & IdB & 6 \\
\hline IdA & 15 & IdB- & 5 \\
\hline IdA- & 14 & IdCCC+ & 4 \\
\hline IdBBB+ & 13 & IdCCC & 3 \\
\hline IdBBB & 12 & IdCCC- & 2 \\
\hline IdBBB- & 11 & IdD & 1 \\
\hline
\end{tabular}

Sumber : (Arif, 2012) 
Variabel bebas pada penelitian ini adalah Profile risiko yang diukur dengan rasio NPL (X1) dan LDR (X2). Penggunaan risiko tersebut disebabkan kedua risiko tersebut dapat diukur dengan menggunakan analisis rasio keuangan

Rasio Non Performing Loan/NPL (X1) digunakan untuk mengukur kemampuan bank sebagai debitur dalam menyanggah risiko kegagalan pengembalian kredit (Darmawan, 2004). Rumus yang digunakan untuk mengukur NPL (SE BI No.13/24/DPNP/2011) sebagai berikut:

$$
\text { NPL }=\frac{\text { Kredit atau pembiayaan bermasalah }}{\text { Total kredit atau pembiayaan }}
$$

Rasio Loan to Deposit Ratio/LDR (X2) digunakan untuk mengukur likuiditas suatu bank (Taswan 2010). Rumus yang digunakan untuk mengukur LDR (SE BI No. 6/23/DPNP/2011) sebagai berikut:

$$
\mathrm{LDR}=\frac{\text { Total kredit kepada pihak ketiga bukan bank }}{\text { Total dana pihak ketiga (DPK) } \ldots . . .(2)}
$$

Variabel terakhir yang digunakan dalam penelitian adalah variabel moderasi berupa Jaminan obligasi yang diukur menggunakan variabel dummy. Kode 0 menunjukkan obligasi tanpa jaminan, sedangkan kode 1 menunjukkan obligasi dengan jaminan (Luciana, 2007). Bristier et al (1994) mengungkapkan investor lebih menyukai obligasi yang dijamin daripada obligasi tanpa jaminan.

\section{HASIL DAN PEMBAHASAN \\ 4.1 Statistik Deskriptif}

Tabel 2. Statistik Deskriptif

\begin{tabular}{llllll}
\hline Variabel & N & Minimum & Maximum & Mean & Std. Deviation \\
\hline Peringkat Obligasi & 64 & 13,000 & 20,000 & 17,969 & 2,468 \\
NPL & 64 & 0,336 & 3,236 & 1,070 & 0,590 \\
LDR & 64 & 0,506 & 1,464 & 0,898 & 0,141 \\
JAMINAN & 64 & 0,000 & 1,000 & 0,375 & 0,484 \\
\hline
\end{tabular}

Sumber: data diolah (2019)

Hasil tabel 2 menunjukkan bahwa dalam penelitian ini sampel yang diambil adalah 64 sampel. Nilai minimum dari peringkat obligasi sebesar 13, nilai maksimum 20 dan nilai rata-rata 17,969. Nilai minimum rasio NPL 33,6 persen yang dimiliki oleh Bank Mayapada Internasional Tbk tahun 2016, nilai maksimum 323,6\% yang dimiliki Bank Capital Indonesia Tbk tahun 2015, dan nilai rata-rata 107\% yang artinya bank memiliki kredit bermasalah terhadap total kreditnya sebesar $107 \%$. Nilai minimum rasio LDR 50,6 persen yang dimiliki oleh Bank Capital Indonesia Tbk tahun 2017, nilai maksimum 146,4\% dimiliki Bank Woori Saudara Indonesia Tbk, dan nilai ratarata $89,8 \%$. Sedangkan nilai minimum jaminan adalah 0 , nilai maksimum 1 dan nilai rata-rata 0,375 . 


\subsection{Hasil Analisis PLS}

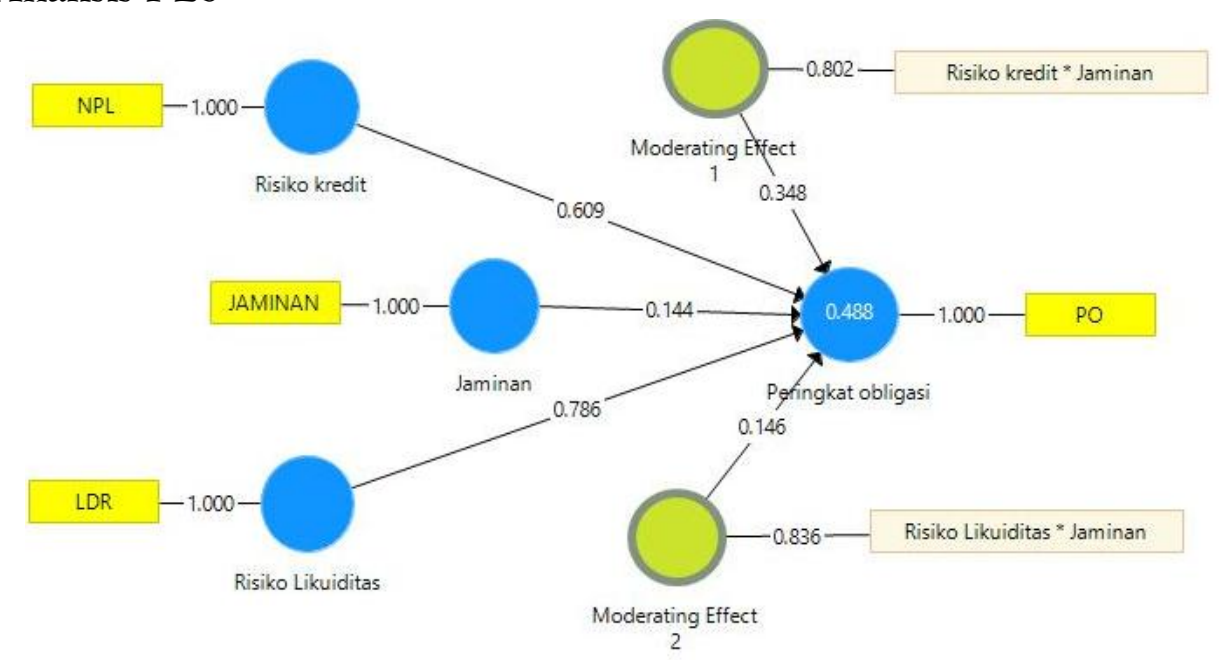

Sumber : data diolah (2019)

Gambar 2. Hasil Output PLS Algorithm

Pada gambar 2 menunjukkan konversi persamaan model pengukuran (outer model) variabel risiko kredit dengan indikator NPL dan variabel risiko likuiditas menunjukkan dengan indikator LDR mempunyai nilai sebesar 1,000 artinya indikator tersebut berpengaruh terhadap variabel masing-masing karena lebih dari 0,7. Variabel jaminan menunjukkan nilai sebesar 1,000 dan variabel peringkat obligasi memiliki nilai sebesar 1,000. Komponen indikator variabel moderasi 2 memiliki nilai sebesar 0,836 artinya komponen variabel moderasi 2 tersebut berpengaruh rendah terhadap variabel peringkat obligasi. Kemudian komponen indikator variabel moderasi 1 memiliki nilai sebesar 0,802, artinya komponen variabel moderasi 1 berpengaruh lebih rendah terhadap peringkat obligasi dibandingkan moderasi 2 .

Pada gambar 2 menunjukkan konversi persamaan model struktural (inner model) dengan koefisien direct effect risiko kredit sebesar 0,609 yang artinya NPL mempunyai pengaruh positif sebesar $60,9 \%$ terhadap peringkat obligasi, risiko likuiditas memiliki koefisien direct effect sebesar 0,786 yang artinya LDR mempunyai pengaruh positif sebesar 78,6\% terhadap peringkat obligasi dan jaminan memiliki koefisien direct effect sebesar 0,144 artinya jaminan mempunyai pengaruh positif sebesar 14,4\% terhadap peringkat obligasi. Kemudian untuk koefisien indirect effect variabel jaminan dalam hubungan risiko kredit terhadap peringkat obligasi sebesar 0,348 artinya jaminan mempunyai pengaruh positif sebesar $34,8 \%$ pada hubungan NPL terhadap peringkat obligasi, pengaruh positif ini menggambarkan jaminan dapat memperkuat hubungan NPL terhadap peringkat obligasi. Koefisien indirect effect jaminan dalam hubungan risiko likuiditas terhadap peringkat obligasi sebesar 0,146 artinya jaminan mempunyai pengaruh positif sebesar $14,6 \%$ pada hubungan LDR terhadap peringkat obligasi, pengaruh negatif ini menggambarkan jaminan dapat memperkuat hubungan LDR terhadap peringkat obligasi. 
Tabel 3. Uji Convergent validity dengan Loading Factor

\begin{tabular}{ccc}
\hline Variabel & Loading Factor & Keterangan \\
\hline Peringkat Obligasi & 1,000 & Valid \\
NPL & 1,000 & Valid \\
LDR & 1,000 & Valid \\
JAMINAN & 1,000 & Valid \\
\hline
\end{tabular}

Sumber : data diolah (2019)

Pada tabel 3 menunjukkan hasil semua variabel yaitu peringkat obligasi, NPL, LDR, dan jaminan memiliki nilai loading factor yang lebih besar dari 0,7. Dengan demikian indikator tersebut dapat dinyatakan valid sebagai pengukur variabel latennya atau telah memenuhi convergent validity.

Tabel 4. Uji Discriminant Validity dengan $A V E$

\begin{tabular}{llll}
\hline Variabel & AVE & $\sqrt{ }$ AVE & Keterangan \\
\hline Peringkat Obligasi & 1,000 & 1,000 & Valid \\
NPL & 1,000 & 1,000 & Valid \\
LDR & 1,000 & 1,000 & Valid \\
JAMINAN & 1,000 & 1,000 & Valid \\
\hline
\end{tabular}

Sumber : data diolah (2019)

Untuk mengukur variabel laten yang ditunjukkan oleh nilai square root of average variance extracted ( $\sqrt{\mathrm{AVE}}$ ) dengan ketentuan apabila $\sqrt{\mathrm{AVE}}$ variabel variabel laten lebih besar dari korelasi variabel laten mengindikasikan indikator-indikator variabel memiliki discriminant validity yang baik. Pada tabel 4 diatas dapat diketahui bahwa semua variabel yaitu peringkat obligasi, NPL, LDR, dan jaminan memiliki nilai $\sqrt{ }$ AVE lebih besar dari 0,5. Dengan demikian indikator tersebut dapat dinyatakan valid sebagai pengukur variabel latennya.

Tabel 5. Uji Reliabilitas dengan Composite Reliability dan Cronbach's Alpha

\begin{tabular}{llll}
\hline Variabel & Composite Reliability & Cronbach's Alpha & Keterangan \\
\hline Peringkat & & & \\
Obligasi & 1,000 & 1,000 & Reliable \\
NPL & 1,000 & 1,000 & Reliable \\
LDR & 1,000 & 1,000 & Reliable \\
JAMINAN & 1,000 & 1,000 & Reliable \\
\hline
\end{tabular}

Sumber : data diolah (2019)

Pada tabel 5 menunjukkan semua variabel yaitu peringkat obligasi, NPL, LDR, dan jaminan memiliki nilai composite reliability dan cronbach's alpha di atas 0,7. Dengan demikian indikator tersebut dapat dinyatakan reliable atau menunjukkan adanya reabilitas alat ukur yang tinggi (Ghozali, 2008:43) sehingga dapat dikatakan masingmasing konstruk memiliki korelasi yang tinggi.

Tabel 6. Model Struktural R Square

\begin{tabular}{ccc}
\hline Variabel & R Square & R Square Adjusted \\
\hline Peringkat Obligasi & 0,488 & 0,444 \\
\hline
\end{tabular}

Sumber : data diolah (2019)

Pengujian terhadap model struktural dilakukan dengan melihat nilai R Squares $\left(\mathrm{R}^{2}\right)$ yang merupakan uji goodness of fit model untuk setiap variabel sebagai kekuatan prediksi dari model struktural. Berdasarkan tabel 6 hasil pengujian menunjukkan nilai $\mathrm{R}^{2}$ 
untuk variabel peringkat obligasi sebesar 0.488 , artinya nilai tersebut mengidikasikan bahwa variabel peringkat obligasi dapat dijelaskan oleh variabel konstruk NPL, LDR, dan jaminan sebesar 48,8\% sedangkan sisanya yaitu sebsar 51,2\% dipengaruhi oleh variabel lain yang tidak terdapat dalam model penelitian ini.

\begin{tabular}{lllllll}
\multicolumn{7}{c}{ Tabel 7. Hasil Uji Hipotesis } \\
\hline Variabel & $\begin{array}{l}\text { Original } \\
\text { Sample } \\
(\mathrm{O})\end{array}$ & $\begin{array}{l}\text { Sample } \\
\text { Mean } \\
(\mathrm{M})\end{array}$ & $\begin{array}{l}\text { Standard } \\
\text { Deviation } \\
(\text { STDEV })\end{array}$ & $\begin{array}{l}\mathrm{T} \text { Statistics } \\
(|\mathrm{O} / \mathrm{STDEV}|)\end{array}$ & $\begin{array}{l}\mathrm{P} \\
\text { Values }\end{array}$ \\
\hline NPL - > Peringkat Obligasi & 0,609 & 0,619 & 0,114 & 5,362 & 0,000 \\
LDR -> Peringkat Obligasi & 0,786 & 0,795 & 0,114 & 6,898 & 0,000 \\
JAMINAN - > Peringkat Obligasi & 0,144 & 0,136 & 0,102 & 1,408 & 0,160 \\
$\begin{array}{l}\text { Moderating Effect 1 - > Peringkat } \\
\text { Obligasi }\end{array}$ & 0,348 & 0,336 & 0,143 & 2,436 & 0,015 \\
$\begin{array}{l}\text { Moderating Effect 2 - > Peringkat } \\
\text { Obligasi }\end{array}$ & 0,146 & 0,155 & 0,156 & 0,939 & 0,348 \\
\hline
\end{tabular}

Sumber : data diolah (2019)

Tabel 7 menunjukkan bahwa hubungan antar variabel NPL yang mengukur risiko kredit dengan peringkat obligasi yaitu $\mathrm{T}$-statistik $>\mathrm{t}$ tabel yaitu 5,362 (> 2,00030), memiliki P-value $0,000<0,05$ dan nilai original sample sebesar 0,609 yang menunjukkan arah hubungan antara NPL dengan peringkat obligasi adalah positif yang artinya variabel NPL secara langsung berpengaruh signifikan terhadap peringkat obligasi dengan arah positif sehingga $\mathrm{H} 1$ ditolak.

Hubungan antar variabel LDR yang mengukur risiko likuiditas dengan peringkat obligasi yaitu T-statistik yaitu 6,898 (> 2,00030), memiliki P-value 0,000 < 0,05 dan nilai original sample sebesar 0,786 yang menunjukkan arah hubungan antara LDR dengan peringkat obligasi adalah positif yang artinya variabel LDR secara langsung berpengaruh signifikan terhadap peringkat obligasi dengan arah positif sehingga $\mathrm{H} 2$ diterima.

Hubungan antar variabel jaminan dengan peringkat obligasi yaitu T-statistik yaitu $1,408(<2,00030)$, memiliki P-value $0,160>0,05$ dan nilai original sample sebesar 0,144 yang menunjukkan arah hubungan antara jaminan dengan peringkat obligasi adalah positif yang artinya variabel jaminan dengan arah positif secara langsung tidak berpengaruh signifikan terhadap peringkat obligasi sehingga $\mathrm{H} 3$ ditolak.

Hipotesis keempat jaminan memperkuat pengaruh risiko kredit terhadap peringkat obligasi. Hasil pengujian menunjukkan nilai T-statistik yaitu 2,436>2,00030 dan memiliki P-value 0,015 $<0,05$ yang artinya variabel jaminan secara langsung berpengaruh memperkuat pada hubungan risiko kredit terhadap peringkat obligasi sehingga $\mathrm{H} 4$ diterima. Hipotesis kelima jaminan memperkuat pengaruh risiko likuiditas terhadap peringkat obligasi. Hasil pengujian menunjukkan nilai T-statistik yaitu $0,939<2,00030$ dan memiliki $P$-value $0,348>0,05$ yang artinya variabel jaminan secara langsung tidak berpengaruh pada hubungan risiko kredit terhadap peringkat obligasi sehingga $\mathrm{H} 5$ ditolak. 


\subsection{Pembahasan}

Berdasarkan identifikasi sampel serta hasil pengujian hipotesis dapat disimpulkan berikut ini. hasil pengujian hipotesis pertama (H1) menunjukkan bahwa terdapat pengaruh secara langsung yang signifikan variabel NPL terhadap peringkat obligasi industri perbankan di bursa efek indonesia (BEI) tahun 2015-2018 dengan arah positif. Variabel NPL menunjukan kemampuan menggambarkan kualitas manajemen bank dalam mengelola kredit bermasalah pada bank (Pramana \& Yunita, 2015). Jika semakin tinggi rasio ini, semakin buruk kualitas kredit pada bank yang menyebabkan jumlah kredit bermasalah dan kemungkinan suatu bank juga dalam kondisi bermasalah. Jika kemungkinan suatu bank dalam kondisi bermasalah, maka peringkat obligasi perusahaan akan turun (Almilia, 2005). Hasil penelitian ini tidak sesuai dengan hasil penelitian yang dilakukan oleh Susanto, Sutejo, dan Marciano (2012); Arpadika (2012), Pramana \& Yunita (2015); Lestari \& Indriani (2016); Prasetyo (2016); serta Malik (2017). dimana penelitian memberikan hasil bahwa NPL berpengaruh negatif terhadap peringkat obligasi bank. Jika NPL semakin tinggi maka semakin buruk kualitas kredit bank sehingga menyebabkan rendahnya peringkat obligasi, begitu pula sebaliknya jika semakin kecil rasio NPL akan berpengaruh pada tingginya peringkat obligasi.

Hasil pengujian hipotesis kedua (H2) menunjukkan bahwa terdapat pengaruh secara langsung yang signifikan variabel LDR terhadap peringkat obligasi industri perbankan di bursa efek indonesia (BEI) tahun 2015-2018 dengan arah positif. Hasil penelitian ini sejalan dengan teori Dendawijaya (2003) yang menyatakan LDR menunjukkan seberapa mampu suatu bank dalam memenuhi kebutuhan masyarakat berupa kredit. LDR yang tinggi akan mencerminkan tingginya efektivitas manajemen bank dalam menyalurkan kredit dengan baik dan akan meningkatkan kepercayaan investor untuk berinvestasi pada bank tersebut, sehingga dengan tingkat likuiditas yang bagus secara tidak langsung akan mengurangi risiko gagal bayar (default) atau pelunasan kewajiban jangka panjangnya (pelunasan obligasi) sehingga berdampak pada naiknya peringkat obligasi. Hal ini sejalan dengan penelitian yang dilakukan Hariyati (2016); Susanto, Sutejo, dan Marciano (2012) serta Fatimah (2015) dengan hasil penelitian rasio LDR berpengaruh positif terhadap peringkat obligasi, yang artinya setiap kenaikan presentase LDR searah dengan kenaikan peringkat obligasi. Semakin tinggi rasio LDR semakin tinggi pula peringkat suatu obligasi, begiu pula sebaliknya semakin kecil rasio LDR maka akan berpengaruh pada rendahnya peringkat obligasi.

Hasil pengujian hipotesis ketiga (H3) menunjukkan bahwa tidak terdapat pengaruh secara langsung yang signifikan variabel jaminan terhadap peringkat obligasi industri perbankan di bursa efek indonesia (BEI) tahun 2015-2018. Variabel jaminan merupakan salah satu aspek penting pada obligasi karena dengan adanya jaminan akan meyakinkan invetor bahwa perusahaan dapat meminimalisir resiko pada obligasi yang akan diterima (Joseph, 2007). Hasil penelitian ini sesuai dengan hasil penelitian yang dilakukan Luciana (2007), Werastuti (2015), dan Sakinah (2017) dan Anto dan Wardjono (2019) menyatakan jaminan tidak memiliki pengaruh pada peringkat obligasi, yang artinya bahwa jaminan tidak dapat dijadikan faktor untuk memprediksi 
peringkat obligasi karena kenaikan jaminan dikatakan tidak berpengaruh terhadap profitabilitas kenaikan tingkat obligasi perusahaan. Namun hasil penelitian ini tidak sesuai dengan penelitian yang dilakukan oleh Magreta dan Nurmayanti (2009), Rika (2011), Yuliana et al. (2011) dan Ayyu (2013), Sari dan Badjra (2016), Hasan dan Dana (2018), menyatakan bahwa perusahaan yang menerbitkan obligasi dengan jaminan dipercaya dapat menaikan kepercayaan investor untuk investasi karena rendahnya probabilitas gagalnya pembayaran kewajiban sebuah perusahaan sehingga merasa aman dan membuat peringkat obligasi perusahaan memiliki rating yang lebih baik.

Hasil pengujian hipotesis keempat (H4) menyatakan bahwa jaminan mampu memoderasi hubungan risiko kredit yang diukur dengan rasio NPL terhadap peringkat obligasi. Perusahaan harus memberikan jaminan pada obligasi untuk menekan risiko kredit karena nantinya akan meminimalisir kemungkinanan kegagalan debitur atau pihak lain untuk melunasi kewajiban bank, baik pokok maupun bunganya pada waktu yang telah ditentukan (Kasidi, 2014). hal ini umumnya terdapat kemungkinan debitur tidak dapat memenuhi kewajiban kepada bank karena berbagai alasan, seperti kegagalan bisnis, karena karakter dari debitur yang tidak mempunya iktikad baik untuk memenuhi kewajiban kepada bank atau memang terjadi kesalahan dari pihak bank dalam proses persetujuan kredit (IBI, 2015:67). Sehingga dengan adanya jaminan perusahaan lebih mampu memberikan rasa aman untuk investor terhadap risiko kredit perusahaan, oleh karena itu jaminan memperkuat hubungan risiko kredit terhadap peringkat obligasi. Sedangkan Hasil pengujian hipotesis kelima (H5) menyatakan bahwa jaminan tidak mampu memoderasi hubungan risiko likuiditas yang diukur dengan rasio LDR terhadap peringkat obligasi. yang artinya walaupun perusahaan memberikan jaminan obligasi tidak ada pengaruh terhadap risiko likuiditas. Dalam hal ini jaminan memperlemah hubungan risiko ketidakmampuan perusahaan dalam memenuhi kewajiban yang telah jatuh tempo terhadap peringkat obligasi.

\section{PENUTUP}

Berdasarkan hasil analisis dapat ditarik kesimpulan bahwa (1) variabel risiko kredit yang diukur dengan Non Performing Loan (NPL) secara langsung berpengaruh signifikan dengan arah positif terhadap peringkat obligasi, (2) variabel risiko likuiditas yang diukur dengan rasio Loan to Deposit Ratio (LDR) secara langsung berpengaruh signifikan dengan arah positif terhadap peringkat obligasi, (3) variabel jaminan secara langsung tidak berpengaruh signifikan terhadap peringkat obligasi, (4) variabel jaminan mampu memoderasi hubungan risiko kredit yang diukur dengan rasio NPL terhadap peringkat obligasi, dalam hal ini jaminan memperkuat hubungan keduanya, (5) variabel jaminan tidak mampu memoderasi hubungan risiko likuiditas yang diukur dengan rasio LDR terhadap peringkat obligasi, dalam hal ini jaminan memperlemah hubungan keduanya. Penelitian ini memiliki keterbatasan yaitu (1) periode penelitian yang pendek berpengaruh pada sampel penelitian yang hanya memperoleh data peringkat obligasi kategori investment grade (AAA, AA, A, BBB) saja, (2) hanya menggunakan dua variabel keuangan saja dan 1 variabel non keuangan dalam memprediksi penentuan peringkat obligasi dengan nilai R2 sebesar $48.8 \%$ sedangkan 
sisanya sebesar $51.2 \%$ dipengaruhi oleh variabel lain yang tidak terdapat dalam model penelitian. Sedangkan saran untuk penelitian selanjutnya yaitu (1) menambah periode penelitian agar mendapatkan jumlah sampel yang lebih banyak serta memperoleh data peringkat obligasi yang masuk kategori investment grade dan non-investment grade, (2) menambahkan variabel pengujian selain risiko kredit dan risiko likuiditas yang mampu mengukur risk profile perbankan seperti risiko pasar, risiko operasional, risiko hukum, risiko stratejik, risiko kepatuhan dan risiko reputasi, (3) menggunakan proksi yang berbeda, selain rasio-rasio yang digunakan dalam penelitian ini, penelitian selanjutnya dapat menambahkan rasio Credit Risk Ratio (CRR), Risk Asset Ratio (RAR), Liquidity Ratio (LR), Deposit Risk Ratio (DRR) serta menambahkan variabel non keuangan seperti reputasi auditor, size perusahaan, umur obligasi dan lain sebagainya dalam menentukan peringkat obligasi.

\section{DAFTAR PUSTAKA}

Abdul Malik, Rizal. (2017). Pengaruh Rasio LDR, NPL, CAR, dan Jaminan Terhadap Peringkat Obligasi Pada Perbankan Yang Listing Di Bursa Efek Indonesia Tahun 2013. 2016. Other thesis, UPN "Veteran" Yogyakarta.

Almilia, Luciana Spica dan Herdiningtyas, Winny (2005), "Analisis Rasio CAMEL terhadap Prediksi Kondisi Bermasalah Pada Lembaga Perbankan Periode 2000-2002”, Jurnal Akuntansi dan Keuangan, Vol.7, No.2.

Andry, Widya. (2005). Analisis Faktor-Faktor yang Mempengaruhi Prediksi Peringkat Obligasi. Buletin Ekonomi dan Moneter dan Perbankan September 2005.

Arif, Bramasta Wisnu. (2012). Pengaruh Manajemen Laba dan Rasio Keuangan Perusahaan Terhadap Peringkat Obligasi. Skripsi Universitas Diponegoro.

Arpadika, Rohyawati Sholihin. (2012). Pengaruh Kinerja Keuangan terhadap Peringkat Obligasi Pada Industri Perbankan yang Terdaftar Di Bursa Efek Indonesia. Skripsi. Sekolah Tinggi Ilmu Ekonomi Perbanas surabaya.

Bencivenga, V. R., \& Smith, B. D. (1991). Financial intermediation and endogenous growth. The review of economic studies, 58(2), 195-209.

Brister, et. al. (1994). "The regulation effect of bond rating on yield". Journal of Finance,pp. 510-531

Darmawan, Komang, (2004). Analisis Rasio-Rasio Bank. Info Bank.

Dewi, Deasy Rahina Khrisna. (2012). Pengaruh Rasio-Rasio Laporan Keuangan Terhadap Peringkat Obligasi Studi Kasus Pada Perbanakan yang Mendapat Peringkat Obligasi dari PT. PEFINDO Tahun 2007-2010. IM Telkom: Bandung.

Fahmi, Irham. (2006). Analisis Investasi dalam Perspektif Ekonomi dan Politik. Bandung: PT. Refika Aditama.

Febriani, Irma, H.S. Nugraha dan Saryadi. (2013) "Analisis Faktor yang Mempengaruhi Peringkat Obligasi Pada Lembaga Keuangan Bank yang Terdaftar di Bursa Efek Indonesia", Jurnal Ilmu Adminstrasi Bisnis, No.1, Vol.1.

Foster, George. (1986). Financial Statement Analysis. Prentice Hall International Inc. Ghozali, Imam. (2008). Structural Equation Modelling, Edisi II, Universitas Diponegoro, Semarang. 
Hadi, E.S., dan Fauziyah, A., (2017). "Pengaruh Keamanan, Kepercayaan dan Resiko Kinerja Terhadap Keputusan Pembelian Secara Online: Studi Kasus Tokopedia.com di Kabupaten Lumajang”. Jurnal Ilmu Manajemen Advantage, Vol. 01, No. 1. Hal 113.

Hamolin, Theresia Vania dan Nila Firdaus Nuzula. (2018). "Analisis Tingkat Kesehatan Bank Berdasarkan Metode Risk Based Bank Rating (Studi Pada Bank Umum Konvensional di Indonesia Periode 2014-2016)", Jurnal Administrasi Bisnis (JAB), Vol. 57, No. 1.

Hariyati, S. (2016). Analisis Faktor-Faktor Yang Mempengaruhi Peringkat Obligasi Pada Perusahaan Perbankan Yang Terdaftar Di Bursa Efek Indonesia Tahun 2011-2014. Skripsi

Hasan, Dinda Aziiza dan Dana, I Made. (2018). Pengaruh Profitabilitas, Likuiditas, Maturity, Jaminan Terhadap Peringkat Obligasi Tertinggi pada Sektor Keuangan di Bursa Efek Indonesia, Jurnal manajemen Unud, Vol.7, No.2, 2018:643-373, Universitas Udayana, Bali.

http://www.idx.co.id/, diakses 20 oktober 2019.

http://www.pefindo.com/, diakses 15 oktober 2019.

Ikatan Bankir Indonesia,. (2015). Manajemen Risiko 1. Gramedia Pustaka Utama.

Jenkinson, N. (2008). Strengthening regimes for controlling liquidity risk. Euro Money Conference on Liquidity and Funding Risk Management (p.9). London: Bank of England.

Kasidi. (2010). Manajemen Risiko. Bogor: Ghalia Indonesia.

Keown. (2011). Manajemen Keuangan: Prinsip dan Penerapan edisi kesepuluh jilid 2. Jakarta: Indeks.

Lestari, Tri Puji dan Astiwi Indriani. (2016). Analisis Pengaruh Non-Performing Loan, Return On Asset, Loan To Deposit Ratio, Dan Bopo Terhadap Rating Bank (Studi pada Bank Perkreditan Rakyat di Indonesia Periode Tahun 2012-2013). Diponegoro Journal Of Management Volume 5, Nomor 4.

Linandarini, Ermi. (2010). Kemampuan Rasio Keuangan dalam Memprediksi Peringkat Obligasi Perusahaan di Indonesia. Skripsi S-1. Universitas Diponegoro.

Almilia, Luciana Spica dan Devi, Vieka. (2007). Faktor-Faktor yang Mempengaruhi Prediksi Peringkat Obligasi Pada Perusahaan Manufaktur yang Terdaftar di Bursa Efek Jakarta. Working Paper.

Dendawijaya, Lukman (2003). Manajemen Perbankan. Jakarta: Ghalia Indonesia.

Manurung, A. H., Tobing W.R.L. (2008). Obligasi Harga Portofolio dan Perdagangannya. Jakarta: ABFI Institute Perbanas.

Merkusiwati, Ni Ketut Lely Aryani. (2007). Evaluasi Pengaruh CAMEL terhadap Kinerja Perusahaan. Buletin Studi Ekonomi Volume 12 No. 1 Tahun 2007.

Nugraheni, H. (2010). Analisis Pengaruh Rasio CAMELS Pada Probabilitas Peringkat Obligasi (Studi Pada Perusahaan Perbankan yang Terdaftar di Bursa Efek Indonesia pada Tahun 2005-2008). Skripsi. Surakarta: Universitas Sebelas Maret. 
Nurmayanti,Poppy dan Magreta. (2009). Faktor-Faktor yang Mempengaruhi Prediksi Peringkat Obligasi Ditinjau dari Faktor Akuntansi dan Faktor Non Akuntansi. Jurnal Bisnis dan Akuntansi 11, pp: 143-154.

Peraturan Bank Indonesia No. 13/1/PBI/2011 tentang penilaian tingkat kesehatan bank umum.

Peraturan Otoritas Jasa Keuangan Nomor 4/POJK.03/2016 Pasal 2 ayat 3 tentang penilaian tingkat kesehatan bank umum.

Pertiwi, Ayyu. (2013). Analisis Faktor-Faktor yang Mempengaruhi Peringkat Obligasi. Skripsi. Universitas Islam Negeri Syarif Hidayatullah Jakarta.

Pramana, Agita Putra dan Irni Yunita. (2015). Pengaruh Rasio-rasio Risk-Based Bank Rating (RBBR) Terhadap Peringkat Obligasi. Jurnal Manajemen Indonesia. Vol.15, No.1. 65-84.

Prasetyo, Yogo Hadi (2016) Analisis Pengaruh Rasio-Rasio Risk Based Bank Rating Terhadap Peringkat Obligasi Perusahaan Perbankan Yang Terdaftar Di Bursa Efek Indonesia. Other thesis, UPN "Veteran" Yogyakarta.

Puryanti, Lina. (2010). Kemampuan Rasio Leverage, Rasio Likuiditas, Rasio Profitabilitas, dan Rasio Produktivitas Dalam Memprediksi Peringkat Obligasi Pada Perusahaan Non Financial yang Terdaftar di Bursa Efek Indonesia. Skripsi. Unisbank.

Raharja dan Sari, Maylia Pramono. (2008). Kemampuan Rasio Keuangan dalam Memprediksi Peringkat Obligasi (PT KASNIC Credit Rating). Jurnal Maksi, Vol.8 No.2.

Rahmawati, Rina. (2005). Manfaat Rasio Keuangan untuk Memprediksi Rating Obligasi, Thesis Universitas Indonesia

Rivai, Veithzal Dkk., (2013) Commercial Bank Management: Manajemen Perbankan Dari Teori Ke Praktik Edisi 1 Cetakan 1. Jakarta: Rajawali Pers.

Sakinah, Putri, Paminto, Ardi dan Kadafi, M. Amin. (2017), Analisis Faktor Keuangan dan Non Keuangan yang Mempengaruhi Prediksi Peringkat Obligasi (Studi Empiris pada Perusahaan Penerbit Obligasi yang terdaftar di Bursa Efek Indonesia Periode 2012. 2014), Fakultas Ekonomi dan Bisnis : Universitas Mulawarman.

Sari, N. M. S. K., \& Badjra, I. B. (2016). Pengaruh Likuiditas, Ukuran Perusahaan, Leverage Dan Jaminan Terhadap Peringkat Obligasi Pada Sektor Keuangan. E-Jurnal Manajemen Universitas Udayana, 5(8), hal: 5041-5069

Setyapurnama \& Norpratiwi. (2008). "Pengaruh Corporate Governance Terhadap Peringkat Obligasi dan Yield Obligasi. Jurnal Akuntansi dan Bisnis (JAB) Universitas Sebelas Maret, Indonesia. Vol 7, No 2.

Tandelilin, Eduardus. (2010). Portofolio dan Investasi Teori dan Aplikasi. Edisi pertama. Yogyakarta: Kanisius.

Taswan. (2010). Manajemen Perbankan. Edisi II. Yogyakarta: UPP STIM YKPN Yogyakarta.

Theofilus Steven Susanto, Bertha Silva Sutejo, dan Deddy Marciano. (2012). "Pengaruh Kinerja Keuangan Bank Terhadap Rating Obligasi Bank di Indonesia". Jurnal Manajemen Teori dan Terapan. Vol 5. No3. Pp 167-179. 
Timothy, J. Gallagher dan Joseph D. Andrew,. (2007). "Financial Management: Principles and Practice", Pearson Education, Inc., United States of America.

Werastuti, D. N. S. (2015). Analisis Prediksi Peringkat Obligasi Perusahaan Dengan Pendekatan Faktor Keuangan Dan Non Keuangan. Jurnal Dinamika Akuntansi Volume 7, Nomor 1.

Yuliana, Rika, Agus Budiatmanto, M. Agung Prabowo dan Taufik Arifin. (2011). Analisis Faktor-Faktor Yang Mempengaruhi Prediksi Peringkat Obligasi Pada Perusahaan Keuangan Yang Terdaftar Di Bursa Efek Indonesia. Simposium Nasional Akuntansi XIV Aceh.

Yuliana, Rika. (2011). Analisis Faktor-Faktor yang Mempengaruhi Prediksi Peringkat Obligasi pada Perusahaan Keuangan yang Terdaftar di Bursa Efek Indonesia. Skripsi. Surakarta: FE UNS. 